\title{
NASIONALISME 'JALAN TENGAH': Mengurai Potensi Benturan Ideologi Nasionalisme Dan Sentimen Ummah Di Era Nation State
}

\author{
Robitul Firdaus \\ Institut Agama Islam Negeri Jember \\ Jl. Mataram No.1, Mangli, Jember, Jawa Timur, 68136 \\ E-mail: robitfirdaus86@gmail.com
}

\begin{tabular}{c|c|c}
\hline Received: & Revised: & Approved: \\
$27 / 05 / 2018$ & $25 / 07 / 2018$ & $20 / 09 / 2018$ \\
\hline
\end{tabular}

DOI: http://dx.doi.org/10.32332/akademika.v23i2.1105

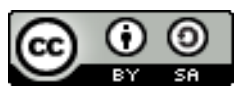

Nasionalisme 'Jalan Tengah': Mengurai Potensi Benturan Ideologi Nasionalisme dan Sentimen Ummah di Era Nation State Licensed Under a Creative Commons Attribution-ShareAlike 4.0 International License

\begin{abstract}
In the study of Islamic political thought, the relation between Islam and nationalism has been a relevant topic to be discussed. This is at least due to two factors. Firstly, there is a concept of ummah in Islam which is considered in contrary with the ideology of nationalism. While ummah is characterized with the solidarity in the name of faith, nationalism is of nationality and geographical borders. Secondly, nationalism and nation state have become a reality accepted by all modern states, including Muslim states. Accordingly, it is assumed that being a loyal Muslim and a good citizen at the same time is impossible. This article is aimed at offering an interface between nationalism and ummah by adopting the positive sides of both. To place nationalism and ummah in a binary opposition is not useful and against the reality. As a result, it is concluded that
\end{abstract}


nationalism can be an asset to achieve the unity and cooperation, particularly in the struggle for independence. However, nationalism can also be a narrow ideology which leads to the negative fanaticism. In this context, the sentiment of ummah can be used as a religious guidance in minimazing and preventing the practice of narrow nationalism. The concept of ummah ensures that a religious bond should be respected besides the bond which is based on the territorial border. On the other hand, nationalism could prevent the sentiment of ummah from falling to religious extremism. Finally, the interface between nationalism and ummah may be applied differently among various Muslim countries.

Keywords: Nationalism, Ummah, and Nation State.

\begin{abstract}
Abstrak
Dalam studi pemikiran politik Islam, relasi antara Islam dan nasionalisme menjadi topik yang masih menarik untuk didiskusikan. Hal ini setidaknya disebabkan oleh dua hal: Pertama, terdapat konsep ummah dalam doktrin Islam yang diyakini berseberangan dengan ide nasionalisme. Ummah meniscayakan solidaritas atas dasar keimanan, sedang nasionalisme mendasarkan pada faktor kebangsaan dan batasan geografis. Kedua, nasionalisme dan negara bangsa merupakan realitas yang dipraktekkan di semua negara modern, termasuk negara-negara Muslim. Sehingga timbul anggapan bahwa tidak mungkin seorang Muslim yang baik dapat sekaligus menjadi warga negara yang baik. Tulisan ini bertujuan untuk menawarkan titik temu antara konsep nasionalisme dan ummah dengan mengambil sisi positif dari keduanya. Meletakkan nasionalisme dan ummah dalam posisi yang bertentangan selain tidak produktif juga bertentangan dengan realitas yang ada. Hasil studi ini menyimpulkan bahwa nasionalisme dapat menjadi modal dalam menuju persatuan dan kerja sama, terutama kaitannya dalam perjuangan kemerdekaan. Meskipun, nasionalisme di sisi lain juga dapat menjadi ideologi sempit yang mengarah pada fanatisme negatif. Di sinilah, sentimen ummah dapat digunakan untuk menjadi panduan agama dalam meminimalisasi dan mencegah praktek nasionalisme sempit. Konsep ummah memastikan bahwa terdapat ikatan keagamaan yang harus dihormati selain ikatan berdasar batasan teritorial. Di sisi lain, nasionalisme mencegah sentimen ummah untuk terjerumus ke dalam ektrimisme agama. Akhirnya, batasan kerjasama dan titik temu antara nasionalisme dan ummah mungkin diaplikasikan berbeda-beda antara satu negara Muslim dengan yang lain.
\end{abstract}

Kata Kunci: Nasionalisme, Ummah, dan Negara Bangsa. 


\section{A. Pendahuluan}

Beberapa waktu yang lalu, media ramai membincangkan lahirnya Perppu No. 2 Tahun 2017 tentang Perubahan atas UU No. 17 tahun 2013 tentang Organisasi Kemasyarakatan. Pro Kontra terhadap Perppu Ormas ini di antaranya disebabkan karena beberapa hari setelah dikeluarkan, Perppu ini digunakan untuk membubarkan salah satu ormas yang dianggap bermasalah, yaitu Hizbut Tahrir Indonesia (HTI). Pembubaran tersebut dilakukan dengan mencabut status badan hukum HTI yang terdaftar di Kementerian Hukum dan HAM. ${ }^{1}$ Ideologikhilafah yang diusung HTI diyakini bertentangan dengan ideologi pancasila dan mengancam keutuhan Negara Kesatuan Republik Indonesia (NKRI). Salah satu akar persoalannya, menurut hemat penulis, adalah dikarenakan penolakan HTI terhadap konsep nasionalisme atau konsep nation-state sebagai turunan dari doktrin khilafah yang mereka kembangkan.

Alasan penolakan terhadap nation state inilah yang kemungkinan juga menyebabkan banyak Pemerintah, tidak terkecuali di banyak negara Timur Tengah, melarang berdirinya Hizbut Tahrir. Penyebabnya tentu saja, karena ideologi khilafah akan sangat berpengaruh dan sekaligus menentang keutuhan dan kesatuan suatu negara, sehingga bisa dikategorikan sebagai perbuatan makar terhadap negara. Meski tidak menggunakan jalur kekerasan, namun ideologi seperti ini dapat dikategorikan ideologi yang membahayakan negara. Sebagaimana tesis dari Saifuddin yang berkesimpulan bahwa ideologi khilafah Hizbut Tahrir Indonesia dapat menjadi ancaman terhadap Negara Kesatuan Republik Indonesia karena sifatnya yang tidak mengenal batasan teritorial. ${ }^{2}$

Secara umum, memang umat Islam terpecah menjadi dua kelompok dalam memandang nation-state. Pertama, mereka yang menerima konsep nation-state (konformis), baik secara sadar atau terpaksa, sebagai suatu proses yang dialami dan harus ditempuh untuk membentuk identitas nasional dan memberikan loyalitas politik nasional.

1 Elik Susanto, "Kemenkumham Beberkan 5 Poin Alasan Pembubaran HTI," Tempo, 19 Juli 2017, https:/ / nasional.tempo.co/read/892605/kemenkumham-beberkan5-poin-alasan-pembubaran-hti diakses tanggal 2 Januari 2018.

2 Baca Saifuddin, "Konsepsi Khilafah (Studi Pemikiran Politik Hizbut Tahrir Indonesia)" (Tesis, Universitas Islam Negeri Sunan Kalijaga, 2007). 
Kedua, menolak sebagian atau seluruh gagasan nation-state. ${ }^{3}$ Di antara alasan penolakan terhadap Negara Bangsa oleh kaum Muslim, menurut Ellie Kedourie, Bernard Lewis, dan Samuel Huntington disebabkan konsep tersebut asing bagi kaum Muslim. Konsep tersebut tidak bisa diinstitusikan dalam masyarakat Muslim, karena ia bertentangan dengan konsep ummah yang berakar kuat dalam masyarakat Muslim. Masyarakat Muslim di manapun berada, merasa menjadi bagian dari satu ikatan, yaitu ummah. Sifat yang khas dari ummah adalah pembagian dunia ini ke dalam dua wilayah, yakni wilayah Islam (dārul Islām) dan wilayah perang atau kafir (dārul harb, dārul kufr). ${ }^{4}$

Makalah ini mencoba kembali mendiskusikan konsep nasionalisme sebagai realitas baru yang menekankan pengakuan atas lokalitas di satu sisi dan konsep ummahdengan nilai universalitasnya sebagai idealitas dalam doktrin Islam di sisi yang lain. Meski keduanya tampak kontradiktif, namun makalah ini akan mencoba mengelaborasi kemungkinan munculnya sebuah 'jalan tengah' sebagai jembatan dan titik temu atas dua pendapat yang berseberangan. Dalam diskursus politik Islam di Indonesia, hal yang demikian dirasa penting setidaknya untuk memastikan dua hal: Pertama, melanjutkan penafsiran Islam yang 'sadar' terhadap kondisi dan tradisi yang berbeda, terutama dalam wilayah sosial politik (mu'amalah-siyasiyyah). Kedua, meminimalisasi potensi disintegrasi yang disebabkan tidak adanya identitas kebangsaan yang disepakati oleh semua pihak. ${ }^{5}$ 40.

${ }^{3}$ James P Piscatori, Islam in a World of Nation State (New York: Cambridge, 1994),

${ }^{4}$ Saiful Mujani, Muslim Demokrat; Islam, Budaya Demokrasi, dan Partisipasi Politik Di Indonesia Pasca Orde Baru (Jakarta: Gramedia Pustaka Utma, 2007), 15-16.

${ }^{5}$ Daniel Dhakidae menyatakan bahwa merupakan suatu hal yang ironis saat tritunggal suci bangsa Indonesia-bahasa, bangsa, dan tanah air-semakin kabur maknanya dan ketiganya terlihat dalam posisi berhadapan. Satu bahasa tidak dengan sendirinya meniscayakan Indonesia menjadi satu bangsa. Riau, tempat asal bahasa Melayu yang menjadi bahasa Indonesia, sering ditimpa isu-isu disintegrasi. Bahasa Indonesia yang dimiliki bangsa ini lebih sering digunakan dalam bentuknya yang tidak tepat. Bahkan satu tanah air tidak berarti menjadi satu bangsa. Aceh, Papua, dan TimorTimur adalah contoh dari hal ini dalam pengertian dan tingkatan yang berbeda. Lihat Benedict Anderson, Imagined Community: Komunitas-Komunitas Terbayang,terj. Omi Intan Naomi (Yogyakarta: Pustaka Pelajar, 2002), xii. 


\section{B. Problem Relasi Islam dan Negara}

Kata negara secara etimologi diterjemahkan dari bahasa Belanda dan Jerman "staat", dalam bahasa Inggris disebut 'state', dan disebut 'etat' dalam bahasa Perancis. Kata agama mulai dibahas dan dipopulerkan sejak berkembangnya negara modern di benua Eropa sekitar abad ke17. Namun demikian, anggapan umum yang diterima adalah bahwa kata 'staat' (state, etat) atau negara dialihkan dari bahasa latin "status" atau "statum". 6 Sedangkan secara terminologi, sebagaimana yang dikemukakan oleh Miriam Budiardjo, bahwa negara merupakan integrasi dari kekuasaan politik, atau organisasi pokok dari kekuasaan politik. Negara juga dapat dikatakan sebagai agency (alat) dari masyarakat yang mempunyai kekuasaan untuk mengatur hubungan-hubungan manusia dan masyarakat dan menertibkan gejala-gejala kekuasaan dalam masyarakat. $^{7}$

Sejauh ini, memang ada tiga aliran pemikiran yang berusaha memberikan jawaban atas pertanyaan apakah Islam sebenarnya juga mengatur masalah kenegaraan. ${ }^{8}$ Pertama, aliran integralistik yang menyebut bahwa Islam menjelaskan segala hal (syumul dan kamil), termasuk tentang kenegaraan.Tokoh yang mewakili aliran ini antara lain Hasan al-Bana, Sayyid Qutb, Rasyid Ridho, dan Abu A'la al-Maududi. Pandangan semacam ini juga banyak diikuti oleh gerakan-gerakan Islam revivalis kontemporer. Kedua, aliran sekuler yang meyakini bahwa Islam sama sekali tidak menyinggung masalah kenegaraan. Keberadaan Islam sama sekali tidak ditujukan untuk mendirikan sebuah negara. Ali Abdur Raziq adalah tokoh yang sangat terkenal mewakili aliran ini sebagaimana ia jabarkan di dalam kitabnya Al-Islam wa Ushul al-Hukm. Menurut Raziq, tidak ada satupun nash dalam Islam yang mewajibkan berdirinya Negara Islam (daulah islamiyah) atau sistem khilafah. ${ }^{9}$ Ketiga, aliran substantif yang

90.

${ }^{6}$ F Isjwara, Pengantar Ilmu Politik (Bandung: Universitas Padjajaran Press, 1999), 2008), 47

7 Miriam Budiardjo, Dasar-Dasar Ilmu Politik (Jakarta: Gramedia Pustaka Utma,

8 Lihat misalnya dalam Munawwir Syadzali, Islam and Govermental System; Teaching, History, and Reflections (Jakarta: INIS, 1991), 95-97.

${ }_{9}$ Lebih lanjut dapat dibaca dalam Ali Abdur Raziq, Khilafah dan Pemerintahan dalam Islam, terj. Afif Mohammad, trans. oleh Arif Mohammad (Bandung: PUSTAKA, 1985) Pendapat ini diperkuat oleh Asghar Ali Engineer yang menyatakan bahwa al-Quran hanya menjelaskan konsep tentang masyarakat, bukan tentang negara. Baca ; Asghar Ali 
menyebutkan bahwa Islam memang tidak sepenuhnya terikat dan terkait dengan masalah kenegaraan, namun juga tidak berarti sama sekali lepas dari negara. Islam memiliki seperangkat nilai-nilai universal yang harus dijalankan dalam sebuah negara. Pendapat ini diikuti oleh Husain Haikal dan beberapa pemikir moderat Indonesia, seperti Nurcholish Madjid dan Syafi' i Ma'arif. ${ }^{10}$

Hanya ada satu aliran yang secara murni menyebutkan Islam sama sekali tidak memiliki keterkaitan dengan konsep negara, sementara dua yang lain masih meyakini adanya keterkaitan tersebut. Menurut penulis, ini menunjukkan bahwa argumentasi dari aliran pertama tidaklah cukup kuat dan merupakan pendapat minoritas pemikir. Di negara Barat sendiri, sekulerisasi di bidang politik ada yang dilaksanakan secara ketat, namun sebagian besar justru tidak ketat dalam penerapannya. ${ }^{11}$ Yusuf Qardhawi bahkan memperkuat keyakinan adanya hubungan Islam dan negara atau Islam dan politik dengan tidak hanya berdasar pada landasan tekstual nash Islam, fakta sejarah, dan karakter Islam yang syumul kamil saja, namun juga mengutip beberapa orientalis yang juga berkeyakinan sama, di antaranya: ${ }^{12}$

1. V. Fitzgerald mengatakan bahwa Islam bukan sekedar agama tapi juga sistem politik. Walaupun akhir-akhir ini muncul dari kalangan kaum muslimin beberapa orang yang menganggap dirinya sebagai modernis berupaya memisahkan kedua hal itu, namun tatanan pemikiran Islam dibangun berdasarkan dua sisi yang saling terkait tersebut, tidak mungkin dipisahkan satu sama lain.

2. Schaht mengatakan: Di samping Islam memberikan pengertian lebih dari hanya sekedar agama, maka dia juga merupakan berbagai teori hukum dan politik. Secara ringkas dapat dikatakan bahwa

Engineer, Devolusi Negara Islam, terj. Imam Mutaqin (Yogyakarta: Pustaka Pelajar, 2000), 325; Baca juga dalam Muhammad 'Abid al-Jabiri, al-Din wa al-Daulah wa al-Tatbiq alSyariah (Beirut: Markaz Dirasat al-Wahdah al-'Arabiyyah, 1996), 13-21.

${ }_{10}$ Pembagian semacam ini juga bisa dilihat dalam Muhyar Fanani, Mempertimangkan Kembali Hubungan Islam dan Demokrasi dalam Islam dan Politik (Yogyakarta: LPPI UMY dan Majelis Tarjih dan Pengembangan Pemikiran Islam PP Muhammadiyah, 2002), 39-40.

${ }^{11} \mathrm{Hal}$ ini misalnya dapat dibuktikan dengan eksistensi partai agama, pendidikan agama, pajak gereja, dan sebagainya. Lihat Masykuri Abdillah, Islam dan Dinamika Sosial Politik di Indonesia (Jakarta: PT Gramedia Pustaka Utama, 2011), 8.

12 Yusuf Qardhawi, Figh Negara; Ijtihad Baru Seputar Sistem Demokrasi, Multipartai, Keterlibatan Wanita di Dewan Perwakilan, Partisipasi dalam Pemerintahan Sekuler, trans. oleh Syafril Halim (Jakarta: Robbani Press, 1997), 5-24. 
Islam adalah suatu sistem yang integral, yang mencakup agama dan negara dan sekaligus.

3. Sir T. Arnold mengatakan: Nabi Muhammad pada waktu yang sama adalah seorang pemuka agama dan kepala negara.

Dalam dua sumber utama agama Islam, Al-Quran dan Sunnah, memang tidak ditemukan istilah atau konsep yang pasti tentang negara. Namun, bukan berarti konsep negara tidak sama sekali disinggung dalam Islam. Secara substantif, terdapat sejumlah dalil yang menunjukkan adanya pemerintahan pada umat Islam, meski hal ini tidak harus dipahami sebagai perintah kewajiban mendirikan sebuah negara. Secara historis sulit rasanya meletakkan Nabi dan al-Khulafa al-Rasyidun hanya sebagai pemimpin agama, sedang fakta sejarah juga mencatat peran mereka sebagai kepala negara dan pemerintahan.

Namun, dikarenakan dalil-dalil terkait negara dan pemeritahan pada umumnya bersifat garis besar, maka terjadi ragam perbedaan pendapat di kalangan ulama tentang persoalan pola hubungan antara Islam dan negara, baik pada masa klasik maupun kontemporer. Misalnya, baik al-Quran maupun Sunnah tidak menyebutkan secara eksplisit apakah negara itu berbentuk republik atau monarki, sistem presidensial atau parlementer. Tidak dijelaskan pula mekanisme pengangkatan kepala negara dan pengaturan kekuasaan eksekutif, legislatid dan yudikatif. ${ }^{13}$ Meski demikian, dapat disimpulkan bahwa secara umum umat Islam tetap memperhatikan faktor agama dalam kehidupan berbangsa dan bernegara. Hal ini dikarenakan sifat dari Islam itu sendiri yang bukan hanya merupakan sistem teologis, namun juga cara hidup (way of life) dalam kehidupan masyarakat dan negara. Islam tidak membedakan sepenuhnya antara hal-hal sakral dan profan, sehingga muslim yang taat menolak pemisahan antara agama dan negara. Di negara-negara Muslim, adopsi sistem sekuler, seperti sistem demokrasi dan penegakan Hak Asasi Manusia, seringkali dilakukan dengan legitimasi keagamaan melalui ijtihad dan penyesuaian-penyesuaian tertentu. ${ }^{14}$

${ }^{13}$ Lihat Fathurrahman Jamil, Mekanisme pengangkatan dan Pemberhentian Kepala Negara" dalam Mawardi (ed), Islam Berbagai Perspektif.Yogyakarta: LPMI, 1995., t.t., 153.

${ }^{14}$ Masykuri Abdillah, Islam dan Dinamika Sosial Politik di Indonesia, 9. 


\section{Doktrin dan Sejarah Nasionalisme}

Nasionalisme berasal dari kata nation yang berarti bangsa. Menurut Kamus Besar Bahasa Indonesia, kata bangsa memiliki arti: (1) kesatuan orang yang bersamaan asal keturunan, adat, bahasa, dan sejarahnya serta berpemerintahan sendiri; (2) golongan manusia, binatang, atau tumbuhtumbuhan yang mempunyai asal-usul yang sama dan sifat khas yang sama atau bersamaan; dan (3) kumpulan manusia yang biasanya terikat karena kesatuan bahasa dan kebudayaan dalam arti umum, dan yang biasanya menempati wilayah tertentu di muka bumi. Beberapa makna kata bangsa di atas menunjukkan arti bahwa bangsa adalah kesatuan yang timbul dari kesamaan keturunan, budaya, pemerintahan, dan tempat. ${ }^{15}$ Pengertian ini berkaitan dengan arti kata suku yang dalam kamus yang sama diartikan sebagai golongan orang-orang (keluarga) yang seturunan; golongan bangsa sebagai bagian dari bangsa yang besar. ${ }^{16}$ Beberapa suku atau ras dapat menjadi pembentuk sebuah bangsa dengan syarat ada kehendak untuk bersatu yang diwujudkan dalam pembentukan pemerintahan yang ditaati bersama.

Kata bangsa mempunyai dua pengertian: pengertian antropologissosiologis dan pengertian politis. Menurut pengertian antropologissosiologis, bangsa adalah suatu masyarakat yang merupakan persekutuan-hidup yang berdiri sendiri dan masing-masing anggota masyarakat tersebut merasa satu kesatuan suku, bahasa, agama, sejarah, dan adat istiadat. Sementara dalam pengertian politis, bangsa adalah masyarakat dalam suatu daerah yang sama dan mereka tunduk kepada kedaulatan negaranya sebagai suatu kekuasaan tertinggi ke luar dan ke dalam. Bangsa (nation) dalam pengertian politis inilah yang kemudian menjadi pokok pembahasan nasionalisme. ${ }^{17}$

Di samping definisi bahasa di atas terdapat beberapa rumusan lain mengenai nasionalisme, di antaranya: ${ }^{18}$

1. Huszer dan Stevenson: Nasionalisme adalah yang menentukan bangsa mempunyai rasa cinta secara alami kepada tanah airnya.

\footnotetext{
${ }^{15}$ Lukman Ali dkk, Kamus Besar Bahasa Indonesia (Jakarta: Balai Pustaka, 1994), 98.

${ }^{16}$ Lukman Ali dkk, 970.

17 Badri Yatim, Soekarno, Islam, dan Nasionalisme (Bandung: Nuansa, 2001), 57-58.

${ }^{18}$ Badri Yatim, 58.
} 
2. L. Stoddard: Nasionalisme adalah suatu keadaan jiwa dan suatu kepercayaan, yang dianut oleh sejumlah besar individu sehingga mereka membentuk suatu kebangsaan. Nasionalisme adalah rasa kebersamaan segolongan sebagai suatu bangsa.

3. Hans Kohn: Nasionalisme menyatakan bahwa negara kebangsaan adalah cita-cita dan satu-satunya bentuk sah dari organisasi politik, dan bahwa bangsa adalah sumber dari semua tenaga kebudayaan kreatif dan kesejahteraan ekonomi.

Beberapa definisi di atas memberi simpulan bahwa nasionalisme adalah kecintaan alamiah terhadap tanah air, kesadaran yang mendorong untuk membentuk kedaulatan dan kesepakatan untuk membentuk negara berdasar kebangsaan yang disepakati dan dijadikan sebagai pijakan pertama dan tujuan dalam menjalani kegiatan kebudayaan dan ekonomi. Dengan gaya berpikir antropologis, Anderson menawarkan pandangan yang lebih positif tentang nasionalisme, ia menyatakan bahwa bangsa atau nation adalah komunitas politis dan dibayangkan (imagined) sebagai sesuatu yang bersifat terbatas secara inheren sekaligus berkedaulatan. Lebih jauh dia memaparkan bahwa bangsa disebut komunitas karena ia sendiri selalu dipahami sebagai kesetiakawanan yang masuk-mendalam dan melebar-mendatar, sekalipun ketidakadilan dan penghisapan hampir selalu ada dalam setiap bangsa. Bangsa disebut sebagai komunitas terbayang (imagined community) karena para anggota bangsa terkecil tidak mengenal sebagian besar anggota lain, bahkan mungkin tidak pernah mendengar tentang mereka. ${ }^{19}$

Nasionalisme erat kaitannya dengan terbentuknya sistem Nation State (Negara Bangsa) yang sejarahnya dapat ditarik jauh pada abad pertengahan saat benua eropa mengalami reformasi pemahaman keagamaan dan revolusi industri. Nation State lahir dari peperangan dan kekacauan di Benua Eropa yang pada akhirnya memunculkan konsep kedaulatan (sovereignity) atau pengakuan atas kekuasaan. Kedaulatan inilah yang kemudian menjadi prinsip utama dalam pembentukan sistem negara modern.Menurut Masrkuri Abdillah, konsep negara atau nation-state seperti sekarang ini baru muncul pada abad ke-16 yang

19 Lihat Benedict Anderson, Imagined Community: Komunitas-Komunitas Terbayang,terj. Omi Intan Naomi, 8-11. 
dikemukakan oleh Nicolo Machiavelli (1469-1527). ${ }^{20}$ Sedang Hans Kohn, dalam bukunya Nationalism: Its Meaning and History, meyakini bahwa nasionalisme berasal dari Eropa Barat pada abad ke-18. Pada abad berikutnya, nasionalisme menyebar di seluruh eropa dan seluruh dunia. ${ }^{21}$ Dalam perkembangannya, nasionalisme Eropa berpindah haluan menjadi persaingan fanatisme nasional antar bangsa-bangsa Eropa yang melahirkan penjajahan terhadap negeri-negeri yang saat itu belum memiliki identitas kebangsaan (nasionalisme) di benua Asia, Afrika, dan Amerika Latin.

Selanjutnya, ide tentang penentuan nasib sendiri mendorong orang-orang untuk mendirikan negara berdaulat sendiri. Negara Bangsa, menurut Nurcholish Madjid, adalah suatu gagasan tentang negara yang didirikan untuk seluruh bangsa atau untuk seluruh umat, berdasarkan kesepakatan bersama yang menghasilkan hubungan kontraktual dan transaksional terbuka antara pihak-pihak yang mengadakan kesepakatan itu. 22 Dalam bukunya, Albert Hourani menyebutkan bahwa era nation state secara global mulai dikenal di dunia Islam, terutama setelah berakhirnya perang dunia kedua. Pada saat itu, negara-negara penjajah yang menduduki wilayah-wilayah Arab mulai melepas negara jajahannya dan banyak terjadi kemerdekaan nasional di beberapa negara Arab. ${ }^{23}$ Pembentukan negara bangsa di negara-negara Muslim juga dipengaruhi oleh runtuhnya kekhalifahan Turki Utsmani yang mengakibatkan kaum Muslim terpecah-pecah dan membentuk ragam negara dengan basis kebangsaan. ${ }^{24}$ Indonesia, sebagai negara dengan populasi Muslim terbesar di dunia, juga berhasil memproklamasikan kemerdekaannya menjelang perang dunia kedua menemui titik akhir pasca menyerahnya Jepang kepada sekutu.

Di Indonesia, nasionalisme melahirkan Pancasila sebagai ideologi negara. Sejarah mencatat terjadi perdebatan yang panjang antara kaum nasionalis religius dan nasionalis sekuler dalam merumuskan pancasila.

${ }^{20}$ Masykuri Abdillah, Islam dan Dinamika Sosial Politik di Indonesia, 3.

${ }^{21}$ Hans Kohn, Nationalism: Its Meaning and History (New York: The Macmilla Company, 1965), 4.

${ }_{22}$ Nurcholish Madjid, Indonesia Kita (Jakarta: Paramadina, 2004), 42.

${ }^{23}$ Albert Hourani, Sejarah Bangsa-Bangsa Muslim (Bandung: Mizan, 2004), 661-66.

${ }^{24}$ Saiful Mujani, Muslim Demokrat; Islam, Budaya Demokrasi, dan Partisipasi Politik Di Indonesia Pasca Orde Baru, 2007, 15. 
Salah satu yang paling terkenal dan menyita energi adalah seputar hilangnya tujuh kata "dengan kewajiban menjalankan syariat Islam bagi pemeluknya" yang terdapat pada piagam Jakarta hasil musyawarah Panitia Persiapan Kemerdekaan Indonesia (PPKI). Meski, ada beberapa upaya pengembalian tujuh kata tersebut pada tahun-tahun berikutnya, rumusan sila pertama tetap berbunyi "Ketuhanan Yang Maha Esa" hingga saat ini. Rumusan pancasila ini sudah dianggap menjadi dasar bagi nasionalisme Indonesia yang sekuler religius. ${ }^{25}$

\section{Ummah}

Kata 'ummah' berasal dari kata amma-yaummu yang berarti menuju, menumpu dan meneladani. Kata 'umm' yang berarti ibu dan 'imam' yang berarti pemimpin juga berasal dari akar kata yang sama. ${ }^{26}$ Dalam al-Quran, kata ummah atau umam dalam bentuk jamaknya disebutkan sebanyak 64 kali dan sebagian besar termasuk ke dalam ayatayat Makkiyyah. Mayoritas kata ummah tersebut berarti bangsa, bagian dari bangsa atau generasi dalam sejarah. Selain itu, ummah juga bermakna kelompok, agama (tauhid), waktu yang panjang, kaum, pemimpin, orangorang kafir, dan manusia seluruhnya. ${ }^{27}$ Kata ummah juga beberapa kali digunakan oleh Rasulullah di dalam piagam Madinah dan mengandung dua pengertian: Pertama, organisasi yang diikat oleh Islam, dan kedua, organisasi umat yang menghimpun jamaah atau komunitas yang beragam atas dasar ikatan sosial politik. ${ }^{28}$

Meski beberapa pemikir mencoba menyamakan istilah ummah dengan nation (bangsa), nation state (negara bangsa), atau community (komunitas), namun padanan ini dianggap tidak tepat. Terminologi ummah memiliki pemahaman yang tidak tercakup atau minimal berbeda dengan konsep-konsep tersebut. Menurut Abdur Rasyid Moten, basis ummah tidak didasarkan pada ras, bahasa, sejarah, dan tidak tergantung pada batas-batas wilayah teritorial. Ummah bersifat universal, meliputi kaum Muslim, dan disatukan oleh ikatan teologi yang kuat dan komprehensif,

${ }^{25}$ Badri Yatim, Soekarno, Islam, dan Nasionalisme, 155.

${ }^{26}$ M. Quraish Shihab, Wawasan al-Quran: Tafsir Maudhu'i atas Pelbagai Persoalan Umat (Bandung: Mizan, 1996), 325.

${ }_{27}$ M. Quraish Shihab, 327.

${ }_{28}$ Muhammad Iqbal, Figh Siyasah: Kontekstualisasi Doktrin Politik Islam (Jakarta: Prenada Media, 2014), 208. 
yaitu Islam. ${ }^{29}$ Kedourie, seorang ahli politik Islam, berpendapat bahwa prinsip ummah membuat masyarakat Muslim, di mana pun berada, akan merasa berada dalam satu ikatan. Di dalamnya, menyatukan halhal yang bersifat temporal dan spiritual atas dasar syariah. Ringkasnya, ummah adalah "solidaritas yang dibangun atas dasar kesamaan iman dan melampaui solidaritas suku atau bahasa dalam masyarakat Muslim." ${ }^{30}$

Muhammad Iqbal menyebutkan setidaknya terdapat lima ciri esensi yang menggambarkan ummah dalam Islam: ${ }^{31}$

1. Ummah terikat dengan aturan syariat dan anggotanya diikat dengan ikatan Islam.

2. Ummah -sebagaimana Islam-memiliki semangat universal. Semua manusia hanya dibedakan berdasarkan kualitas ketakwaannya, bukan atas dasar ras, suku, komunitas, dan batas-batas wilayah.

3. Persaudaraan dan persatuan di dalam ummah dibangun tidak atas nilai-nilai primordial, seperti kekeluargaan, darah, atau keturunan. Bahkan Islam menegasikan hal yang demikian. ${ }^{32}$ Persaudaraan dalam Islam didirikan atas dasar keimanan. “Sesungguhnya orangorang yang beriman itu bersaudara,"33 demikian firman Allah dalam al-Quran.

4. Konsep ummah tidak mendukung prinsip kolektivisme kaum komunis, tapi juga tidakpro individualisme versi kapitalis. Islam mengakui hak-hak individu dan membolehkan mereka untuk mencari dan mengumpulkan harta. Namun, di waktu yang sama, Islam juga mewajibkan pembayaran zakat dan menganjurkan sedekah sebagai sarana mencapai kesejahteraan bersama. Pendek kata, meski tiap orang berhak memiliki dan mengumpulkan harta sebanyak-banyaknya, tapi terdapat hak orang lain yang harus ditunaikan di dalam harta yang ia miliki dan kumpulkan.

5. Atas dasar prinsip-prinsip tersebut, nasionalisme dan teritorialisme yang membagi dan membatasi kepentingan dan pengaturan

\footnotetext{
${ }^{29}$ Muhammad Iqbal, 207.

${ }^{30}$ Saiful Mujani, Muslim Demokrat; Islam, Budaya Demokrasi, dan Partisipasi Politik Di Indonesia Pasca Orde Baru, 2007, 15.

${ }^{31}$ Saiful Mujani, 209-10.

${ }^{32}$ QS. Al-Mujadalah (58): 22.

${ }^{33}$ QS. Al Hujurat (49): 10.
} 
anggota ummah berdasarkan wilayah, warna kulit, bahasa, atau yang lain dianggap berseberangan dengan prinsip universal Islam.

\section{E. Nasionalisme Vs Ummah}

Banyak pakar yang meyakini bahwa ummah dan nasionalisme merupakan dua konsep yang saling bertentangan. Huntington misalnya, yakin bahwa kuatnya loyalitas masyarakat muslim terhadap ikatan ummah menyebabkan sintesis antara Islam dan ide negara bangsa menjadi tidak mungkin. Menurutnya, loyalitas kaum muslim terhadap ikatan ummah mengalahkan loyalitas mereka terhadap nation state atau nasionalisme. ${ }^{34}$ Dalam konteks ini, Azra menuturkan bahwa setidaknya ada tiga alasan yang menyebabkan nation-state seringkali dibenturkan dengan Islam. Pertama, secara historis, nation-state tidak memiliki landasan sejarah (ahistoris) dalam Islam. Ia lahir dan berkembang di Barat. Kedua, secara konseptual, nation-state berlandaskan pada nilai-nilai etnisitas, kulural, wilayah, dan bahasa, sedangkan Islam berlandaskan pada persamaan agama. Ketiga, secara institusional, nation-state berdiri secara diametris dengan institusi khiläfah yang meniscayakan semua wilayah Islam pada suatu religiously based super-state. ${ }^{35}$

Dalam banyak hal sebetulnya ditemukan beberapa kesamaan antara cita-cita politik Islam dengan sistem modern yang datang dari Barat, karena masing-masing juga memiliki ide dan nilai-nilai yang bersifat universal. Namun, karena filosofi antara keduanya berbeda, tidak jarang yang sering dimunculkan justru adalah pertentangan antara keduanya. Menyangkut hal-hal yang fundamental, terkadang banyak negara-negara Muslim yang mengalami dilema dalam menggabungkan keduanya dalam negara modern. ${ }^{36}$ Dalam konteks pertentangan antara prinsip nasionalisme dan ummah misalnya, penting untuk menjaga kekuatan dan persatuan internal melalui penerapan paham nasionalisme di satu sisi, namun konsep ummah meniscayakan adanya keterhubungan dan persatuan global atas nama agama di sisi yang lain.

${ }^{34}$ Saiful Mujani, Muslim Demokrat; Islam, Budaya Demokrasi, dan Partisipasi Politik Di Indonesia Pasca Orde Baru, 2007, 17.

${ }^{35}$ Azyumardi Azra, Pergolakan Politik Islam dari Fundamentalisme, Modernisme, Hingga Post-Modernisme (Jakarta: Paramadina, 1996), 11-12.

${ }^{36}$ Masykuri Abdillah, Islam dan Dinamika Sosial Politik di Indonesia, 101-2. 
Absennya keimanan dari rumusan nasionalisme menimbulkan kritik dari sebagian tokoh Islam. Mereka meyakini bahwa hal ini menyebabkan lemahnya kesatuan dunia Islam. Ali Muhammad Naqvi, misalnya, menyatakan bahwa Islam tidak sesuai dengan nasionalisme karena keduanya berlawanan secara ideologis. Kriteria nasional sebagai basis bangunan komunitas ditolak Al-Quran, karena ia hanya bersifat nasional-lokal sementara Islam mempunyai tujuan universal. Alasan lain adalah spirit sekular dalam nasionalisme yang menghendaki pemisahan tegas antara agama dan politik.

Kritik terhadap nasionalisme juga dikemukakan oleh Muhammad Iqbal. Menurutnya, salah satu ideologi di balik nafsu imperialisme dan kolonialisme modern adalah paham nasionalisme Barat. Atas nama nasionalisme, negara-negara Barat berlomba-lomba dan merasa berhak menjajah bangsa-bangsa yang lain. Bangsa-bangsa Barat mendukung daerah yang dikuasai Turki Utsmani untuk memisahkan diri atas dasar semangat nasionalisme. Ideologi nasionalisme telah menjadi ancama serius bagi perdamaian dan ketentraman dunia. Lebih lanjut menurut Iqbal, jika negara-negara Muslim menjadikan nasionalisme sebagai basis sistem politik, maka ada dua kemungkinan yang akan dihadapi, yaitu nasionalisme menjadi langkah awal menuju ateisme atau Islam hanya akan menjadi pedoman etika saja. Dalam bahasa lain, nasionalisme menuntut agar Islam menyingkir ke belakang dan meletakkannya sebagai urusan pribadi, bukan sebagai penegak kehidupan berbangsa dan bernegara. ${ }^{37}$

Penolakan yang disampaikan oleh Iqbal terlihat tidak hanya didasarkan pada nilai-nilai ideal yang tertuang dalam dalil-dalil atau sejarah Islam, namun juga melihat fakta kekinian yang ia saksikan sendiri pada masa imperialisme. Ia menyaksikan bagaimana Barat memecah belah dunia Islam dan melakukan praktik kolonilaisasi di India atas dasar nasionalisme sempit. Secara teoritis, Iqbal mengemukakan bahwa pendirian Islam tentang nasionalisme berbeda dengan pandangan Barat. Nasionalisme dalam Islam tidak didasarkan atas kesatuan bahasa, wilayah teritorial, sosial budaya atau ekonomi, tapi pada kepercayaan

${ }^{37}$ Muhammad Iqbal, Figh Siyasah: Kontekstualisasi Doktrin Politik Islam (Jakarta: PrenadamediA, 2014), 201-12. 
dan tradisi bersama yang dimiliki umat Islam. ${ }^{38}$ Oleh sebab itu, tidak tepat kalau prinsip nasionalisme sempit ala Barat semacam ini diterapkan dalam negara-negara Muslim di dunia.

Senada dengan Iqbal, Imam Khomeini juga menolak nasionalisme dan mencurigainya sebagai alat propaganda untuk memecah belah Islam. Bagi Khomeini, paham nasionalisme adalah salah satu sebab timbulnya bencana yang dihadapi oleh Muslim di dunia. Penyebar nasionalisme adalah orang-orang yang memusuhi Islam dan merupakan agen kolonialisme. Perkembangan gerakan nasionalis di negara-negara Muslim bukan didorong oleh kesadaran internal umat Islam, melainkan hasil dari kolonialisasi Barat. Khomeini mengindetifikasi nasionalisme sebagai kekuatan kolonial yang mendorong rasa solidaritas nasional umat Islam justru untuk tujuan perpecahan. Ia menulis: Rencana kekuatan super power dan rekan-rekan yang mendukung mereka terhadap negara-negara Muslim adalah untuk memecah belah beragam kelompok Islam, seperti kurdi, Arab, Turki, Persia, dan lain sebagainya. Bahkan membuat mereka bermusuhan antar satu dengan yang lain. Padahal Allah telah Allah menyatakan sebagai saudara.Hal ini bertentangan dengan ketetapan Islam dan al-Quran.

\section{F. Titik Damai}

Ada tiga istilah dalam bahasa Arab yang biasa digunakan untuk mewakili istilah nasionalisme, yaitu: 'Ashabiyyah (kesukuan, rasisme, nasionalisme, solidaritas group), Qawmiyyah (nasionalisme, etnosentrisme), dan Wathaniyyah (nasionalisme, patriotisme). Meski ketiganya memiliki tekanan yang berbeda dalam kaitannya dengan nasionalisme, namun sering kali juga digunakan untuk merujuk pada konsep yang sama dan cenderung susah untuk dibedakan antar satu dengan yang lain. ${ }^{39}$

'Ashabiyyah misalnya didefinisikan oleh Ibn Khaldun sebagai keterikatan dan solidaritas kelompok yang menjadi unsur penting dalam memastikan eksistensi sebuah suku bangsa menhadapai ancaman dari luar. 'Ashabiyyah ini timbul karena faktor-faktor pertalian darah atau

${ }^{38}$ Muhammad Iqbal, Fiqh Siyasah: Kontekstualisasi Doktrin Politik Islam, 2014.

39 "Zaman - 2012 - Islam and Nationalism A Contemporary View.pdf," t.t., 393400. 
pertalian kaum dan rasa cinta seseorang terhadap nasab dan golongannya. Hal ini akan menimbulkan perasaan senasib sepenanggungan dan melahirkan persatuan di antara mereka. Adanya solidaritas kelompok merupakan suatu keharusan bagi bangunan suatu dinasti yang kuat dan besar. Namun, sebuah kekuasaan akan mampu bertahan dalam solidaritas kelompok hanya bila ditopang oleh agama. 'Ashabiyyah yang merupakan sisa-sisa tradisi jahiliyyah harus dibingkai dan ditopang oleh kerangka dan pondasi agama. ${ }^{40}$

Bagi Ibnu Khaldun, agama dan solidaritas kelompok tidak semestinya dipertentangkan, karena justru akan menyebabkan disintegrasi. Kecintaan dan solidaritas kelompok sejatinya merupakan insting alamiah manusia yang tidak mungkin ditentang Islam. Pada permulaan dakwah Nabi Muhammad SAW, peran solidaritas dan dukungan suku Bani Hasyim sangat besar saat mayoritas kaum Quraisy memboikot Nabi dalam banyak bidang. Oleh sebab itu, saat Rasulullah ditanya, "apakah seseorang yang mencintai kaumnya tergolong fanatisme ('ashabiyyah)?" Rasul menjawab: Tidak, fanatisme ialah bila seseorang mendukung kaumnya atas suatu kedzaliman." (HR. Ahmad)

Kecintaan terhadap tanah air dan rasa solidaritas ('ashabiyyah) merupakan modal penting untuk memastikan kuat atau lemahnya suatu negara. Tanah air merupakan tempat kelahiran atau tempat tinggal. Diriwayatkan bahwa ketika Nabi sampai di kota madinah, ia berdoa: "Ya Allah jadikanlah kami mencintai Madinah sebagaimana atau melebihi kami mencintai Makkah." (HR. Bukhari). Dalam riwayat Imam Bukhari, Rasul juga disebutkan akan memacu kendaraannya lebih cepat saat datang dari bepergian dan melihat dinding kota Madinah karena kecintaannya terhadap Madinah. Hadis ini menurut Ibnu Hajar al-'Asqalany menunjukkan disyariatkannya mencintai tanah air serta merindukannya. ${ }^{41}$

Mematuhi ajaran yang diberikan oleh Nabi Muhammad Saw. berarti memutuskan hubungan dengan orde sosial kesukuan dan

${ }^{40}$ Muhammad Iqbal dan Amin Husein Nasution, Pemikiran Politik Islam dari Masa Klasik hingga Indonesia Kontemporer (Jakarta: Prenadamedia, 2010).

${ }^{41}$ Ibnu Hajar al-'Asqalany, Fathu al-Bari Syarhu Shahih al-Bukhari, Juz III (Beirut: Dar al-Ma'rifah, 1397H). 
mengidentifikasikan dirinya dengan kesatuan baru..$^{42}$ Namun afiliasi dan loyalitas kepada komunitas yang berdasarkan keimanan tidak berarti bahwa Islam melarang ikatan-ikatan lain selain ikatan berdasar keimanan. Alih-alih, Islam menganjurkan bentuk-bentuk ikatan lain, seperti ikatan keluarga, selama tidak bertentangan dengan Islam. ${ }^{43}$

Menurut Iqbal, meski secara filosofis, nasionalisme negara modern tidak sejalan dengan prinsip Islam, namun bukan berarti Islam melarang berdirinya negara-negara Muslim yang dibatasi oleh geografis dan perbedaan sosial budaya. Pembatasan sebuah negara diperbolehkan demi kemudahan pengaturan umat Islam asal tidak membatasi atau bahkan menghilangkan pandangan sosial umat Islam. Iqbal sendiri mendukung berdirinya negara Pakistan demi kemandirian bangsa Muslim mengatur urusannya sendiri. Tapi bagi Iqbal, lahirnya negara-negara tersebut tidak semestinya menjadi faktor pemecah belah persatuan keluarga besar dunia Islam. Di sini Iqbal berusaha memberikan alternatif titik temu antara unsur nasionalisme dan ummah. Berdirinya sebuah negara dan kecintaan terhadap tanah air tidak semestinya menghilangkan ikatan persaudaraan yang berbasis keimanan. Sehingga, republik-republik yang mayoritas penduduknya beragama Islam tersebut memiliki semangat persatuan dan merupakan bagian tak terpisahkan dari satu keluarga besar dunia Islam. Nasionalisme yang ditolak Iqbal adalah nasionalisme sempit yang mengantarkan pada kompetisi tanpa moralitas sebagaimana dipraktekkan Barat.

Asumsi dasar bahwa nasionalisme adalah penyebab perpecahan juga sebenarnya tidak selamanya dapat dibenarkan. Karena nasionalisme di satu sisi, memang memecah dunia Islam dari kesatuan wilayah Imperium Turki Utsmani menjadi Turki, Irak, Mesir, Lebanon, Suriah, Arab Saudi, Kuwait, Palestina, dan lain-lain. Imperium Mughal menjadi India, Pakistan, Bangladesh. Namun di sisi lain, nasionalisme justru mempersatukan puluhan kesultanan yang terjajah menjadi satu negara besar, Indonesia. ${ }^{44}$ Menurut Muttaharri, setidaknya ada tiga aspek

${ }^{42}$ Adhyaksa Dault, Islam dan Nasionalisme: Reposisi Wacana Universal Dalam Konteks Nasional (Jakarta: Pustaka al-Kautsar, 2005).

${ }^{43}$ Adhyaksa Dault, 62.

${ }^{44}$ Yudian Wahyudi, Maqāşid Syarī'ah dalam Pergumulan Politik; Berfilsafat Hukum Islam dari Harvard ke Sunan Kalijaga (, , 2007), 21. (Yogyakarta: Pesantren Nawesea Press, t.t.). 
positif dari nasionalisme: Pertama, nasionalisme dapat membawa pada persatuan yang lebih kuat antara masyarakat pada sebuah bangsa. Kedua, Masyarakat pada satu bangsa memiliki kesepahaman antar satu dengan yang lain, sehingga menyebabkan hubungan yang lebih baik di antara mereka. Ketiga, nasionalisme dapat mendorong masyarakat untuk mencintai tanah air dan saling melayani antar satu dengan yang lain.

Dalam menjelaskan hubungan antara Islam dan nasionalisme, Hasan al-Banna, seorang tokoh pergerakan Islam, bahkan memaparkan bahwa apabila yang dimaksud dengan nasionalisme adalah kerinduan atau keberpihakan terhadap tanah air, keharusan berjuang membebaskan tanah air dari penjajahan, ikatan kekeluargaan antar masyarakat, dan pembebasan negeri-negeri lain maka nasionalisme dalam makna demikian dapat diterima dan bahkan dalam kondisi tertentu dianggap sebagai kewajiban. ${ }^{45} \mathrm{Di}$ sini, al-Banna melihat nasionalisme sebagai satu semangat yang bisa diarahkan menjadi gerakan positif, terutama dalam kaitannya dengan persatuan dan pembebasan negeri dari penjajahan asing. Sebagian sarjana Muslim bahkan berpendapat bahwa piagam madinah yang dibuat oleh Nabi secara spirit mendukung konsep nasionalisme modern, bukan nasionalisme yang didasarkan atas agama. ${ }^{46}$

Secara umum, memang ada dua sikap kontradiktif yang lahir dari sementara pemikir politik Islam menyikapi paham nasionalisme. Sebagian mendukung dan sebagian yang lain menolak secara penuh. Masing-masing memiliki basis argumentasi keagamaan sesuai dengan tafsir yang mendukung pendapat mereka. Harus diakui bahwa nasionalisme memiliki sisi positif dan negatif bila dipandang dari perspektif siyasah, khususnya saat dikomparasikan dengan konsep ummah. Nasionalisme mampu menyatukan ragam suku, budaya dan agama, namun memisahkan saudara seagama yang berbeda teritorial. Nasionalisme dianggap anak yang lahir dari rahim kolonialisme dan imperialisme, namun nasionalisme juga menjadi salah satu semangat di balik perlawanan terhadap ideologi tersebut. Gerakan kemerdekaan di

${ }^{45}$ Adhyaksa Dault, Islam dan Nasionalisme: Reposisi Wacana Universal Dalam Konteks Nasional, 17. 230.

${ }^{46}$ Yusdani, Fiqh Politik Muslim Progresif (Yogyakarta: Kaukaba Dipantara, 2015), 
beberapa negara jajahan, termasuk negara-negara Muslim, salah satunya ditopang oleh semangat pembebasan atas nama nasionalisme.

Kemudian, sebagian kalangan yang mengkritisi nasionalisme menganggap paham ini sebagaibagian dari ideologi sekuler yang memarjinalkan peran agama.Bagi mereka, nasionalisme telah menolak klaim agama sebagai elemen dasar persatuan.Agama atau apapun yang dianggap sebagai ancaman terhadap persatuan dan kepentingan nasional harus dikorbankan demi kepentingan nasionalisme. Pendapat semacam ini tidak dapat sepenuhnya dibenarkan, karena nasionalisme juga mungkin menjadikan agama sebagai instrumen penguatnya. Agama tidak hanya digunakan sebagai alat legitimasi, namun juga menjadi ruh atau spirit di balik semangat nasionalisme. Dalam konteks ini, agama dan nasionalisme justru bekerja sama dan mengambil sisi positif dari masing- masing.

Nasionalisme juga dianggap telah memecah belah dunia Islam dari persaudaraan yang semestinya dibatasi dengan bingkai ummah. Padahalinternasionalisasi Islam tidak sepenuhnya mustahil terjadi di era nation-state ini. Dalam batas-batas tertentu, internasionalisasi itu sudah ada yang berjalan, misalnya melalui Islamic Development Bank dengan tawaran sistem ekonomi Islam atau NGO Islam internasional lainnya. Era globalisasi sangat memungkinkan internasionalisasi terwujud lebih mudah. Pada konteks globalisasi ini, sistem nation-state bahkan diyakini tidak akan dapat berlangsung lama. Lahirnya Uni Eropa misalnya juga semakin memperkuat asumsi semakin melemahnya doktrin nation-state di Eropa yang menjadi tempat kelahiran nation-state sendiri. Ada dua alasan yang menyatakan adanya pengaruh globalisasi terhadap nation-state. Pertama, globalisasi diyakini akan melenyapkan nation-state. Argumentasinya adalah karena arus revolusi informasi menyebabkan dunia semakin tidak memiliki sekat-sekat wilayah dan pelaku-pelaku sosial bisa melakukan interaksi melewati batas-batas negara. ${ }^{47}$ Kedua, globalisasi adalah ancaman terhadap nation-state, sebab

${ }^{47}$ Kenichi Ohmae, Hancurnya Negara Bangsa; Bangkitnya Negara Kawasan dan Geliat Ekonomi Regional di Dunia Tak Berbatas, terj. Ruslani (Yogyakarta: Qalam, 2002). 
globalisasi menyebabkan negara dapat kehilangan kontrol atas sumber ekonominya. ${ }^{48}$

Dengan demikian, hadirnya sistem kekuasaan Islam international tidaklah sepenuhnya mustahil bila mengacu pada fakta semacam ini. Meski tentu saja juga tidak bisa sepenuhnya dibilang rasional. Penyebabnya, karena globalisasi atau internationalisasi yang ada saat ini masih bergerak di seputar kepentingan politik atau ekonomi, sehingga benturan yang terjadi pun adalah benturan ekonomi atau politik. Berbeda dengan sistem khiläfah yang sangat mengedepankan ideologi keagamaan sebagai modal gerakan. Tentu saja, penerimaan dunia international dan benturan yang mungkin terjadi juga akan berbeda. Belum lagi fakta bahwa pada ranah ideologi ini, dalam Islam masih terjadi ragam pendapat berbeda. Misalnya dalam membahas hubungan agama dan negara.

Meski Lewis, Huntington dan Bendix sangat pesimis, kalau bukan antipati, terhadap kemungkinan lahirnya titik damai antara ide ummah dan nasionalisme, namun pendapat mereka tersebut tidak dapat digeneralisasi pada praktek di seluruh negara. Bendix mencontohkan praktek sintesa antara nasionalisme dan sentimen ummah di Timur Tengah yang menurutnya keputusan dilematis dari para penguasa dan pimpinan Muslim. Di satu sisi, romantisme ummah begitu populer, sedang di sisi yang lain, terdapat pentingnya pembangunan ekonomi yang mungkin bisa melemahkan sentimen tersebut. ${ }^{49}$ Menurut penulis, sama seperti demokrasi, meski memiliki prinsip-prinsip umum, namun praktek demokrasi mungkin bervariasi antar satu negara Muslim dengan yang lain. Masing-masing akan melakukan penyesuaian disesuaikan dengan nilai dan norma-norma lain yang hidup di negara tersebut. Demikian juga, kompromi antara pentingnya paham nasionalisme dan sentimen ummah pada prakteknya dapat beragam dan sangat dipengaruhi oleh faktor sosial politik dan sosial budaya masing-masing negara.

Penolakan terhadap ideologi nasionalisme secara total atas nama sentimen ummah berpotensi melahirkan ekstrimisme yang justru kontraproduktif. Tidak sedikit dari pelaku terorisme yang menjadikan

${ }^{48}$ Moh. Mahfud MD, Perdebatan Hukum Tata Negara Pasca Amandemen Konstitusi (Jakarta: LP3ES, 2007).

${ }^{49}$ Saiful Mujani, Muslim Demokrat; Islam, Budaya Demokrasi, dan Partisipasi Politik Di Indonesia Pasca Orde Baru (Jakarta: Gramedia Pustaka Utama, 2007), 16-17. 
penindasan saudara seiman mereka di "negara lain" sebagai justifikasi terhadap perbuatan teror di negeri mereka sendiri. ${ }^{50}$ Indonesia dengan nasionalismenya dianggap sebagai negara kafir, karena tidak menjadikan agama dengan ideologi ummah sebagai dasar kebijakan negara. Dalil agama kemudian digunakan untuk menghalalkan perbuatan yang sama sekali jauh dari misi utama agama itu sendiri. ${ }^{51}$ Oleh karena itu, ajaran cinta tanah air tidak semestinya diartikan sebagai musuh dari ide ummah dalam Islam.

Bagi penulis, alih-alih didudukkan sebagai ideologi yang saling berhadap-hadapan, konsep ummah lebih tepat dijadikan ramburambu religius bagi praktek nasionalisme di negara-negara Muslim. Ini untuk menghindari pemaknaan dan praktek nasionalisme sempit yang mungkin timbul di era persaingan modern. Konsep ummah memberikan panduan bahwa nasionalisme bukanlah nilai tertinggi yang harus dibela dan dikedepankan di atas kepentingan apapun juga. Terdapat nilai-nilai kemanusiaan, keadilan, dan kesejahteraan bersamasebagaimana ajaran Islam yang penting untuk didukung dan diperjuangkan melampaui batasan teritorial dan geografis. Mempertahankan dan memperjuangkan kepentingan nasional jangan sampai mengabaikan nilai-nilai universal, termasuk prinsip keagamaan. Nasionalisme sempit berpotensi untuk menjadi pemicu peperangan dan kompetisi tidak sehat antar negara. Maka, doktrin ummah menjadi relevan untuk mengimbangi potensi tumbuhnya efek negatif dari pemahaman nasionalisme secara sempit. Di sisi lain, sentimen ummah sebenarnya justru menjadi semacam tali perekat dan memperkokoh nasionalisme Indonesia. Sentimen agama telah mengambil peranan penting sejak masa perjuangan kemerdekaan dalam menjaga persatuan Indonesia.

Dalam konteks ini, Haji Agus Salim mengingatkan agar ideoologi nasionalisme tidak dipisahkan dengan keimanan, tapi harus "karena Allah dan menurut perintah Allah semata-mata." Bagi Salim, nasionalisme yang terlepas dari bimbingan universalisme agama akan sangat agresif dan berbahaya. Ia mencontohkan penggunaan slogan cinta tanah air oleh

${ }^{50}$ Zulfi Mubarak, "Fenomena Terorisme di Indonesia: Kajian Aspek Teologi, Ideologi dan Gerakan" 15 (2012): 240-54.

51 Tentang catatan beberapa aksi terorisme "Muslim" di Indonesia Muhammad Subhan, "Pergeseran Orientasi Gerakan Terorisme Islam di Indonesia (Studi Terorisme Tahun 2000-2015)," Journal of International Relations 2, no. 4 (2016): 59-67. 
penguasa-penguasa Barat yang justru berakhir pada praktek penjajahan. Salim khawatir nasionalisme dijadikan legitimasi oleh para pembela dan pemujanya untuk menghalalkan langkah-langkah agresif dan ekspansif untuk menaklukkan bangsa lain..$^{2}$ Maka, pertimbangan prinsip keadilan dan nilai-nilai agama yang universal sebagaimana sentimen ummah harus menjadi panduan atau minimal penyeimbang dalam penerapan ideologi nasionalisme.

Indonesia dapat dijadikan obyek studi sintesa antara konsep nasionalisme dan sentimen ummah yang melahirkan nilainilai kompromistis sebagaimana tergambar di dalam Pancasila dan Pembukaan UUD 1945. Dalam alinea pertama, misalnya, disebutkan "bahwa sesungguhnya kemerdekaan itu ialah hak segala bangsa dan oleh karena itu, maka penjajahan di atas dunia harus dihapuskan karena tidak sesuai dengan perikemanusiaan dan perikeadilan." Rumusan semacam ini lahir karena dalam sejarahnya nasionalisme Indonesia dipengaruhi oleh para pemikir yang belajar dari Barat dan Timur Tengah. Meski sempat terjadi ketegangan politik dalam penentuan dasar negara antara kelompok nasionalis dan Islam, namun mayoritas mereka bersepakat bahwa nilai-nilai agama tetap menjadi bagian penting dalam pengelolaan negara. Menjelaskan relasi positif antara universalisme Islam dan lokalitas nasionalisme, Soekarno menulis:

Dimana-mana orang Islam bertempat, bagaimanapun djuga djauhnja dari negeri tempat kelahirannja, di dalam negeri jang baru itu ia masih mendjadi satu bahagian dari pada rakjat Islam, dari pada persatuan Islam. Dimana-mana orang Islam bertempat, disitulah ia harus mentjintai dan berkerdja untuk keperluan negeri itu dan rakyatnja. Inilah nasionalisme Islam! Sempit-budi dan sempit-pikiranlah nasionalis jang memusuhi Islamisme serupa ini. Sempit-budi dan sempit-pikiranlahia, oleh karena ia memusuhi suatu azas, jang, walaupun internasional dan interrasial, mewadjibkan pada segenap pemeluknja yang ada di Indonesia, bangsa apa merekapun djuga, mentjintai dan bekerdja untuk keperluan Indonesia dan rakyat Indonesia djuga adanja! ${ }^{53}$

\footnotetext{
${ }^{52}$ Susmihara, "Islam dan Nasionalisme di Indonesia" IV. no. 1 (2016): 50-61.

${ }^{53}$ Sukarno, "Dibawah Bendera Revolusi (ttp: Panitya Penerbit Dibawah Bendera Revolusi, 1963), 7.," t.t.
} 
Beberapa kebijakan luar negeri pemerintah Indonesia dalam hal ini dapat dilihat sebagai aplikasi dari sentimen ummah.Terlepas dari kemungkinan adanya kepentingan politik jangka pendek, dukungan penuh kepada Palestina, bantuan terhadap Muslim Rohingya, dan keterlibatan Indonesia dalam isu-isu Islam di dunia internasional sedikit banyak dipengaruhi oleh nilai-nilai ummah. Dengan demikian, konsep ummah dapat berkontribusi secara positif terhadap nasionalisme dalam dua ranah sekaligus; ke dalam untuk memperkokoh dan ke luar untuk berjuang atas nama keadilan dan kemanusiaan. Sebaliknya, nasionalisme juga turut andil dalam memastikanpenggunaan sentimen ummah yang tidak berlebihan dan cenderung mengarah pada ekstrimisme.

\section{G. Simpulan}

Benturan antara konsep nasionalisme dan ummah tidak dapat terhindarkan saat melihat keduanya dari perspektif epistemologis dan historis. Nasionalisme dianggap lahir dan besar dari peradaban Barat, sementara ummah berasal dari rahim Islam. Maka,meski keduanya berkaitan dengan ikatan solidaritas masyarakat, wajar jika banyak hal dari kedua konsep tersebut yang kemudiandibentur-benturkan. Di antaranya, terkait dengan ikatan nasionalisme yang terbatas pada luas teritorial, sedang sentimen ummah lebihbersifat universal.Nasionalisme diyakini sebagai bagian dari politik sekuler, sementara ummah adalah doktrin inti dari siyasah syar'iyyah (politik Islam). Mempertentangkan nasionalisme dengan ummah tidak selaras dengan realitas konsep nation state yang dianut oleh semua negara Muslim. Praktik sintesa keduanya bukanlah suatu hal yang mustahil terjadi. Kerja sama antara nasionalisme dan sentimen ummah justru dapat menunjukkan wajah Islam yang lebih damai. Nasionalisme plusummah dapat disebut sebagai nasionalisme religius atau nasionalisme Islam. Tentu saja, praktik sintesa ini dapat berbeda-beda pada tiap negara Muslim di dunia, termasuk di Indonesia[.] 


\section{REFERENSI}

Adhyaksa Dault. Islam dan Nasionalisme: Reposisi Wacana Universal Dalam Konteks Nasional. Jakarta: Pustaka al-Kautsar, 2005.

Albert Hourani. Sejarah Bangsa-Bangsa Muslim. Bandung: Mizan, 2004.

Ali Abdur Raziq. Khilafah dan Pemerintahan dalam Islam, terj. Afif Mohammad.

Diterjemahkan oleh Arif Mohammad. Bandung: PUSTAKA, 1985.

Asghar Ali Engineer. Devolusi Negara Islam, terj. Imam Mutaqin. Yogyakarta:

Pustaka Pelajar, 2000.

Azyumardi Azra. Pergolakan Politik Islam dari Fundamentalisme, Modernisme, Hingga Post-Modernisme. Jakarta: Paramadina, 1996.

Badri Yatim. Soekarno, Islam, dan Nasionalisme. Bandung: Nuansa, 2001.

Benedict Anderson,. Imagined Community: Komunitas-Komunitas Terbayang,terj. Omi Intan Naomi. Yogyakarta: Pustaka Pelajar, 2002.

F Isjwara. Pengantar Ilmu Politik. Bandung: Universitas Padjajaran Press, 1999.

Fathurrahman Jamil. Mekanisme pengangkatan dan Pemberhentian Kepala Negara" dalam Mawardi (ed), Islam Berbagai Perspektif.Yogyakarta: LPMI, 1995., n.d.

Hans Kohn. Nationalism: Its Meaning and History. New York: The Macmilla Company, 1965.

Ibnu Hajar al-'Asqalany. Fathu al-Bari Syarhu Shahih al-Bukhari, Juz III. Beirut: Dar al-Ma'rifah, 1397H.

James P Piscatori. Islam in a World of Nation State. New York: Cambridge, 1994.

Kenichi Ohmae. Hancurnya Negara Bangsa; Bangkitnya Negara Kawasan dan Geliat Ekonomi Regional di Dunia Tak Berbatas, terj. Ruslani. Yogyakarta: Qalam, 2002.

Lukman Ali dkk. Kamus Besar Bahasa Indonesia. Jakarta: Balai Pustaka, 1994.

M. Quraish Shihab. Wawasan al-Quran: Tafsir Maudhu'i atas Pelbagai Persoalan Umat. Bandung: Mizan, 1996. 
Masykuri Abdillah. Islam dan Dinamika Sosial Politik di Indonesia. Jakarta: PT Gramedia Pustaka Utama, 2011.

Miriam Budiardjo. Dasar-Dasar Ilmu Politik. Jakarta: Gramedia Pustaka Utma, 2008.

Moh. Mahfud MD. Perdebatan Hukum Tata Negara Pasca Amandemen Konstitusi. Jakarta: LP3ES, 2007.

Mubarak, Zulfi. "Fenomena Terorisme di Indonesia: Kajian Aspek Teologi, Ideologi dan Gerakan" 15 (2012): 15.

Muhammad 'Abid al-Jabiri. al-Din wa al-Daulah wa al-Tatbiq al-Syariah. Beirut: Markaz Dirasat al-Wahdah al-'Arabiyyah, 1996.

Muhammad Iqbal. Figh Siyasah: Kontekstualisasi Doktrin Politik Islam. Jakarta: Prenada Media, 2014.

- - . Figh Siyasah: Kontekstualisasi Doktrin Politik Islam. Jakarta: PrenadamediA, 2014.

Muhammad Iqbal, dan Amin Husein Nasution. Pemikiran Politik Islam dari Masa Klasik hingga Indonesia Kontemporer. Jakarta: Prenadamedia, 2010.

Muhammad Subhan. "Pergeseran Orientasi Gerakan Terorisme Islam di Indonesia (Studi Terorisme Tahun 2000-2015)." Journal of International Relations 2, no. 4 (2016): 59-67.

Muhyar Fanani. Mempertimangkan Kembali Hubungan Islam dan Demokrasi dalam Islam dan Politik. Yogyakarta: LPPI UMY dan Majelis Tarjih dan Pengembangan Pemikiran Islam PP Muhammadiyah, 2002.

Munawwir Syadzali. Islam and Govermental System; Teaching, History, and Reflections. Jakarta: INIS, 1991.

Nurcholish Madjid. Indonesia Kita. Jakarta: Paramadina, 2004.

QS. Al Hujurat (49): :, n.d.

QS. Al-Mujadalah (58):, n.d.

Saifuddin. "Konsepsi Khilafah (Studi Pemikiran Politik Hizbut Tahrir Indonesia)." Tesis, Universitas Islam Negeri Sunan Kalijaga, 2007.

Saiful Mujani. Muslim Demokrat; Islam, Budaya Demokrasi, dan Partisipasi Politik Di Indonesia Pasca Orde Baru. Jakarta: Gramedia Pustaka Utma, 2007. 
- - . Muslim Demokrat; Islam, Budaya Demokrasi, dan Partisipasi Politik Di Indonesia Pasca Orde Baru. Jakarta: Gramedia Pustaka Utama, 2007.

Sukarno. "Dibawah Bendera Revolusi (ttp: Panitya Penerbit Dibawah Bendera Revolusi, 1963), 7.," n.d.

Susanto, Elik. "Kemenkumham Beberkan 5 Poin Alasan Pembubaran HTI." Tempo, 19 Juli 2017. https://nasional.tempo.co/read/892605/ kemenkumham-beberkan-5-poin-alasan-pembubaran-hti.

Susmihara. "Islam dan Nasionalisme di Indonesia" IV. no. 1 (2016): 50- 61.

Yudian Wahyudi. Maqāş̧id Syarī'ah dalam Pergumulan Politik; Berfilsafat Hukum Islam dari Harvard ke Sunan Kalijaga (, , 2007), 21. Yogyakarta: Pesantren Nawesea Press, n.d.

Yusdani. Figh Politik Muslim Progresif. Yogyakarta: Kaukaba Dipantara, 2015.

Yusuf Qardhawi. Figh Negara; Ijtihad Baru Seputar Sistem Demokrasi, Multipartai, Keterlibatan Wanita di Dewan Perwakilan, Partisipasi dalam Pemerintahan Sekuler. Diterjemahkan oleh Syafril Halim. Jakarta: Robbani Press, 1997.

"Zaman - 2012 - Islam and Nationalism A Contemporary View. pdf," n.d. 